This article has been published in the Journal of Transport \& Health. This is the final version submitted for publication. The full reference is:

Mackett R L and Thoreau R (2015) Transport, social exclusion and health, Journal of Transport and Health, 2, 610-617, doi: 10.1016/j.jth.2015.07.006, available from http://dx.doi.org/10.1016/i.jth.2015.07.006. 


\title{
Transport, social exclusion and health
}

Roger L. Mackett ${ }^{1}$ and Roselle Thoreau

Centre for Transport Studies, University College London, Gower Street, London, WC1E 6BT, Great Britain.

E-mail: r.mackett@ucl.ac.uk and r.thoreau@ucl.ac.uk

Telephone: +44 2076791554 .

\begin{abstract}
This paper explores the nature of social exclusion and how transport contributes to it by providing barriers to access. Transport influences health in several ways: by providing physical activity through walking and cycling, and by providing access to healthy food, recreation facilities and healthcare. Transport produces externalities including traffic casualties and vehicle emissions. These effects impinge on society unequally with socially excluded people able to access fewer facilities than others but suffering more from the externalities. The paper is concluded by discussion about various interventions that have been used to address social exclusion by reducing the barriers to access.
\end{abstract}

\section{Highlights}

- Transport is a significant factor in social exclusion.

- Transport affects health directly through walking and cycling.

- Transport provides access to healthy food, healthcare and recreation facilities.

- Barriers to travel include cost, lack of information and psychological barriers.

- A variety of transport interventions have been used to address social exclusion.

\section{Key words}

social exclusion; barriers to travel; transport externalities; access; interventions

\footnotetext{
${ }^{1}$ Corresponding author
} 


\section{Introduction}

Social exclusion, a term first coined in France by Lenoir (1974), has long been recognised as a problem in society, linked to poor access to resources causing personal and physical harm (Sen, 2000). In 1997, the British government established the Social Exclusion Unit (2003) which published 'Making the Connections: Final Report on Transport and Social Exclusion' to explain how poor accessibility can contribute to social exclusion and how improvements to the transport system can increase social inclusion. As the report explains, the effects of transport-related social exclusion are wide: individuals can be affected personally, financially and physically. When people, for whatever reason, are unable to access healthcare services, parks, education or welfare services their health is likely to suffer. Transport externalities such as road casualties, vehicle emissions and noise can all affect health adversely.

This paper is a narrative review of the ways in which transport-related social exclusion impacts upon health and some of the interventions which have been designed to address the issue. The examples cited are from Great Britain, which may provide useful ideas for implementation elsewhere. The paper builds upon the work on this subject carried out in the report 'Health on the Move 2' (Mindell et al., 2011) by examining the links between transport-related social exclusion and health more explicitly, and the updated work in that report on the health implications of inequalities in travel opportunities (Mackett, 2014d). 'Health on the Move 2' (Mindell et al., 2011) was produced by the Transport and Health Study Group to update the original 'Health on the Move' report, summarising the available empirical evidence on the relationships between transport and health.

There are many papers on transport and health in this and other journals There are a number of papers on the links between transport and social exclusion such as Delbosc and Currie (2011) and papers in the special issue of the journal Transport Policy (volume 6, issue 3 ) but only one of those contained evidence on the possible effects on health (Lucas et al., 2009). The effects of transport-related social exclusion on health are rarely considered. The objective of this paper is to consider this topic and how transport interventions can be used to help address social exclusion with consequential positive impacts on health.

\section{Social exclusion}

In this paper the term social exclusion is used to mean circumstances where individuals or groups of people are unable to participate in activities or to access goods, services and opportunities that are available to others as a fundamental part of belonging to society.

Examples of excluded groups include those living in poverty who face financial exclusion to services, disabled people who face physical exclusion and minority groups who face language and/or cultural exclusion (Social Exclusion Unit, 2001). People who are socially excluded are more likely to spend less time in education, more likely to be unemployed, and have higher rates of ill health.

\section{Transport-related social exclusion}

Access to the transport system allows individuals to participate in many aspects of society. Transport-related social exclusion is more likely to affect some groups than others. 
- Income. Those in lower income and socio-economic groups are most likely to be excluded from full access to transport. For example, in the lowest income quintile in Great Britain, $48 \%$ of households did not have access to a car compared to $14 \%$ in the highest income quintile in 2013 (Department for Transport, 2014). There is evidence (Horten and Reed, 2010) that government spending on transport is strongly biased towards higher income groups, unlike education, housing and health.

- Disability. $9 \%$ of the population over the age of 16 in 2013 had mobility difficulties (Department for Transport, 2014). They made 572 trips on average compared with 977 by those without mobility difficulties. Inaccessible transport prevents some disabled people from taking jobs or attending interviews (Campion et al., 2003).

- Age. Older people are more likely than others to have given up driving, have limited walking ability and find it difficult to navigate stairs or steps which can make many forms of public transport difficult or inaccessible (Mackett, 2014c). Mobility difficulties increase with age: $3 \%$ of adults under 50 years have mobility difficulties in 2013 (Department for Transport, 2014). This increased to 12\% for those aged 60-69 years and 31\% for those aged 70+ (Department for Transport, 2014). Young people may be excluded from the job market and leisure facilities because they cannot afford to learn to drive or afford bus fares (pteg, 2010). Children may be unable to enjoy after-school activities because they live with a single parent who is employed and so unable to take them or unable to afford the cost of travel (pteg, 2010).

- Gender. Fewer women than men hold a driving licence (Department for Transport, 2014) but more women than men say that they do not use buses because they feel unsafe (Department for Transport, 2013).

- Ethnicity. Members of black and Asian ethnic groups in Britain make over $15 \%$ fewer trips on average than white people and have lower car ownership (Department for Transport, 2014).

There are barriers to travel which affect some socially-excluded people more than the rest of the population.

- Cost. Public transport is becoming increasingly expensive (Maddison et al., 2014) and those with cars must pay for parking. For some people, travel (using either private or public modes) is too expensive for them to make essential journeys: one in four unemployed people say that their job search is inhibited by the cost of travel to interviews (Social Exclusion Unit, 2003). The cost of transport can be a major barrier to engaging in education and work for young people (ACEVO Commission on Youth Employment, 2012). Increases in bus fares in Manchester to support the increased cost of supporting the Concessionary Travel Pass for older people led to some young people not being able to travel to after-school activities (pteg, 2014). Small increases in bus fares can have a large impact on low income families, especially for participation in after-school activities (Greater Manchester Transport Research Unit, 2008).

- Availability of transport. $77 \%$ of jobseekers in British cities outside London do not have regular access to a car, van or motorcycle (Johnson and Mackie, 2013). Public transport does not always link homes to essential places. For example, $40 \%$ of households lived over 30 minutes from a hospital in 2012 (Department for Transport, 2014). In 2013 24\% of households did not have a frequent local bus service and 15\% did not have a reliable one (Department for Transport, 2014). 
- Psychological barriers. Some women, disabled and members of ethnic minorities have a fear of using public transport. (pteg, 2010). People may feel unsafe using public transport in the areas they need to reach or feel unsafe travelling at the time of day needed to access services. Bostock (2001) argues that the lack of a car may have negative impacts on the welfare of families because those with low incomes, particularly lone mothers with young children, may be forced to walk through neglected and depressed areas because of the lack of a car or suitable public transport.

- Physical barriers. Some disabled and older people have difficulty travelling because of barriers such as steps, steep slopes and obstructions on the pavement (Mackett et al., 2011).

- Facilities. Lack of facilities can make it difficult for some groups to travel. For example, a lack of benches and bus shelters can stop older or disabled people from accessing public transport (Mackett et al., 2011).

- Information. Poor quality travel information may mean that people do not know which services are available (Balcombe and Vance, 1998). This can be difficult for infrequent travellers, people who need to reach new areas (for example, the newly employed) and disabled people. Travel information can be provided in the form of timetables, maps and route information. It can be provided both prior to travel and in the course of the journey, either on paper or electronically via the internet on home computers or mobile devices such as phones. Whilst electronic information has advantages because it can be provided at low marginal cost, people on low incomes may not be able to afford the technology, many older people grew up before the technology became common and so do not use it, and many devices are not suitable for use by some disabled people.

\section{How transport-related social exclusion affects health}

There are various ways in which transport affects health, directly and indirectly as shown in Figure 1. Walking and cycling provide physical activity. Transport provides access to various facilities that can improve health such as recreation facilities, both indoor and outdoor, shops that sell healthy food, health and medical facilities, and the opportunity to meet with friends, family and others which can enhance well-being and mental health. Access is easier for those with more income, which is provided through access to employment, with higher incomes potentially available to those who have had access to education and training. Transport also has external effects such as casualties on the road, vehicle emissions which can lead to lung disease and other health conditions, excessive noise which can impair hearing, and community severance with heavily trafficked roads reducing pedestrian access to health-providing facilities. The effects of social exclusion on the relationship between health and transport, as shown in Figure 1, are discussed below where it is shown that those who are socially excluded tend to have poorer access while the externalities of transport have greater impact on areas where those who are socially excluded tend to live. 


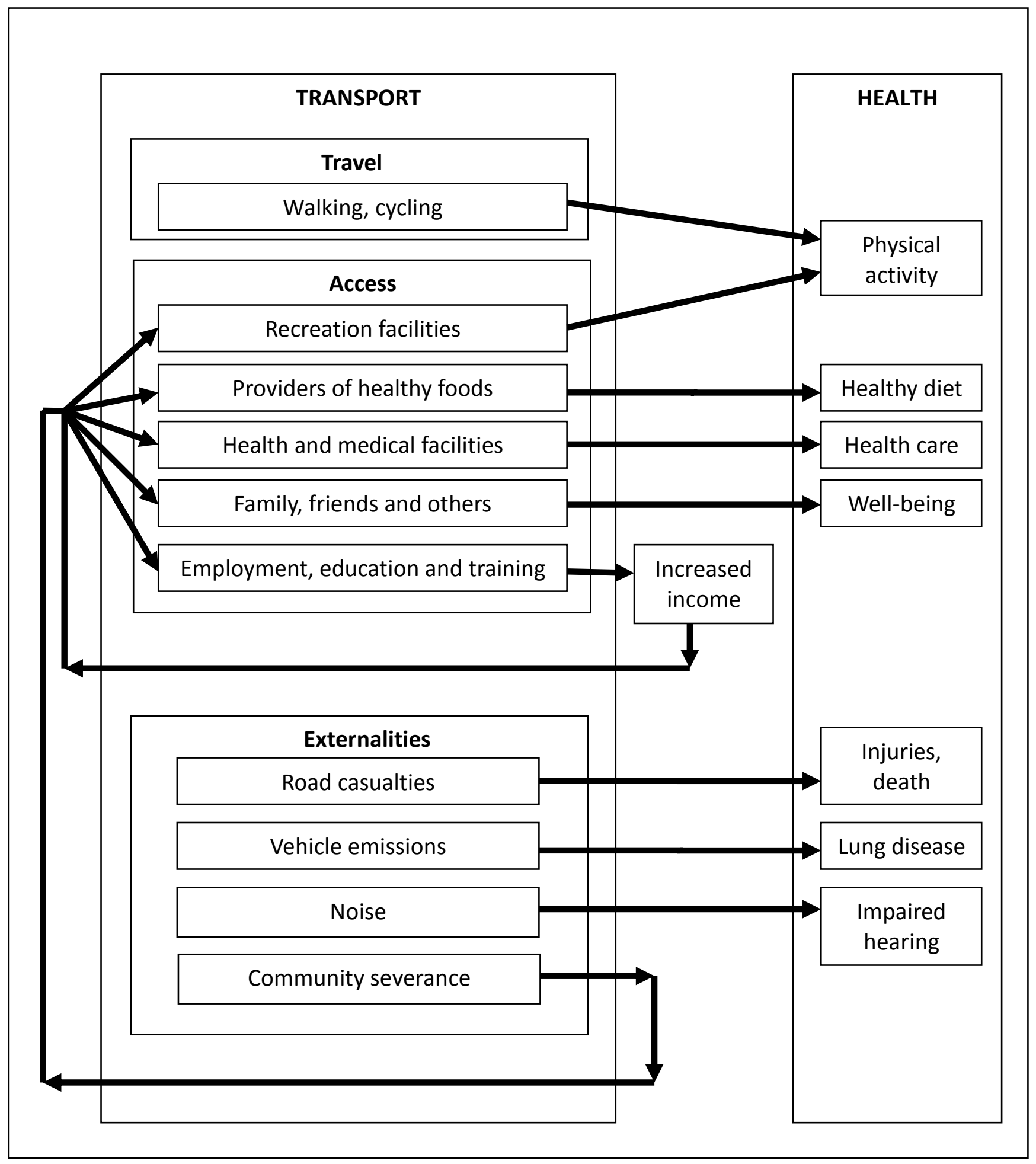

Figure 1 The influences of transport upon health 


\subsection{Travel}

Brisk walking has been identified as protective of physical health (Saelens et al., 2003). Andersen et al. (2000), in a study in Copenhagen, Denmark, found that those who cycled to work spent an average of three hours a week cycling and reduced the relative risk of allcause mortality to $72 \%$ of that of those who did not commute by bicycle. Kwaśniewska et al. (2010) carried out a study in Poland which found that active commuting (walking and cycling) was associated with decreased likelihood of abdominal obesity, lower high-density cholesterol, and elevated triglycerides in men and decreased levels of abdominal obesity in women.

Table 1 shows that the distance walked each year tends to decrease with income apart from the top group. Cycling tends to increase with income, especially the highest income group. This means that those with the highest incomes not only travel furthest by car, they also travelled furthest using active travel (walking and cycling combined).

Table 1. Distance in kilometres per head per year by mode, by real household income quintile in Great Britain, 2012

\begin{tabular}{lrrrrrr}
\hline & Walk & Bicycle & Car & Bus & Rail & Total \\
\hline Lowest real income & 328 & 66 & 4,330 & 835 & 508 & 6,382 \\
Second level & 294 & 56 & 5,826 & 706 & 512 & 7,768 \\
Third level & 269 & 78 & 8,374 & 602 & 707 & 10,349 \\
Fourth level & 267 & 91 & 10,366 & 414 & 1026 & 12,526 \\
Highest real income & 286 & 131 & 12,867 & 389 & 2310 & 16,622 \\
\hline All & 290 & 85 & 8342 & 589 & 1002 & 10706 \\
\hline
\end{tabular}

Source: Department for Transport (2014)

Note: 'Bus' includes coach; 'other' modes are included in the 'Total' column.

\subsection{Access}

People with higher incomes tend to travel further implying greater access to opportunities, as shown in Table 1. Income is positively correlated with both health (Rowlingson, 2011) and car ownership (Department for Transport, 2014). Ellaway et al. (2003) concluded that car use has positive benefits for health, since they found that, after controlling for age, sex and socio-economic circumstances, people in car owning households had lower overall mortality, lower rates of long-term illness, fewer symptoms, and better mental health. This is despite evidence that there is a relationship between the time spent in cars and obesity (Frank et al., 2004).

For older people, access to public transport is important to allow them to access places which provide them with physical activity (Marsden et al., 2007). The destinations that older people feel are important to be able to reach include day centres and parks, both of which offer physical activity and encourage healthy behaviour. Low income groups tend to live in areas with the poorest access to green spaces (CABE, 2010), which are good for exercise. In younger groups as well, participation in many activities which could be beneficial for health does not occur because of a lack of access by transport. For example, a survey in Scotland found that the availability and accessibility of sports facilities has a high impact on participation, especially of those aged between 16 and 34 (Murray, 2006). A lack of public 
transport to access the countryside leads to non-participation in leisure activities in the countryside (Brown, 2008).

There are places in Britain where affordable healthy food is difficult to access, often exacerbated by the effects of large supermarkets being located on the edge of urban areas (Furey et al., 2001). For example, some people living in Hackney in London, parts of which are very deprived, have problems accessing healthy food shops but can reach many fast food outlets selling cheap unhealthy food (Bowyer et al. 2009). There is evidence that locating new stores in deprived areas can change shopping patterns but may not lead directly to changes in dietary patterns (Cummins et al., 2008) so additional means may be necessary to improve diet.

Transport-related social exclusion has major impacts on access to healthcare. It is estimated that 1.4 million people a year either miss, refuse or do not seek healthcare due to transport difficulties (DTLR, 2001). A lack of transport makes not only accessing healthcare difficult but also related services such as collecting medication. Access to healthcare without private transport is particularly difficult. A third of people who did not own a car found it difficult to get to the hospital compared to $17 \%$ of those who did own a car (SEU, 2003). In one town, half the survey respondents without a car had never visited a dentist compared with $15 \%$ of those with one (Countryside Agency, 2001).

Studies have shown that elderly people who participate in activities outside their home report higher levels of wellbeing than those who do not (Ravulaparthy et al., 2013). Social isolation in older people is linked to an increased mortality risk (House et al., 1988). Social isolation is about interacting with other people in the community: the Health White Paper 'Healthy Lives, Healthy People' (Department of Health, 2010) says, in Paragraph 1.41: "Maintaining social networks, being part of a community and staying active all benefit health and wellbeing in later life". For many older people travel itself is an important social tool, one which is sometimes viewed as more important that the journey destination (Marsden et al., 2007).

Lucas and Jones (2009) found people who are socially excluded because of the lack of transport feel isolated and have to rely on other people to get around. Difficulties accessing transport can lead to social isolation in older people, for example, as a result of giving up driving. Musselwhite and Haddad (2010) examined the travel needs of older people by conducting three focus groups with 26 current car drivers aged 68 to 90 years old and then interviews with 31 older ex-drivers aged 65 to 92 years old. They found that ceasing to drive caused many changes in travel behaviour, including anxiety about being able to go shopping, to hospital, and to attend doctors' surgeries, with respondents mentioning feelings of depression and annoyance, particularly amongst those 'forced' to give up driving following advice from others or a driving incident. Isolation and exclusion from society were mentioned as resulting feelings.

\subsection{Externalities}

Rates of road traffic injuries show steep social class gradients with the rates increasing with increasing deprivation for most types of road user, particularly child pedestrians (Department for Transport, 2008). Children from lower socio-economic households spend 
more time walking or playing near roads than their more affluent peers (Vaganay et al., 2003). In the early 2000s, children from the lowest social class were five times as likely to die as pedestrians from road injuries than children from the highest (Department for Transport, 2008). Analysis of child road traffic casualties from 2004 to 2008 found a marked social gradient: injury rates varied from one child in 206 in Preston in the north of England to one in 1,158 Kensington \& Chelsea, a wealthy part of London. Child road casualties are highest for families in large council estates typically in outer suburbs of large provincial cities (Road Safety Analysis Ltd, 2010).

In Lothian, Scotland, road injury rates were higher in areas with more rented housing, higher proportions of lone parent households, low car ownership and more unemployment (Abdalla et al., 1998). The paper showed that pedestrian injuries were higher in areas of higher population density, where residents from the lowest social class and older people tended to live (Abdalla et al., 1998).

In general, the adverse effects of car use are concentrated where car travel occurs rather than where car owners live. Exposure to traffic pollution has a direct impact upon health. The highest emissions from cars are in the poorest areas (King and Stedman, 2000). Much research has been carried out on the impact of traffic pollution on human health. The effects of road pollution are associated with early mortality and additional hospital admissions (Colvile et al., 2001). For example, studies have shown that residential proximity to heavy traffic increases the risk of asthma (Salam et al., 2008). Different groups face different levels of exposure with rural groups having the least exposure and people living in high density areas of cities, who tend to have relatively low incomes, facing higher exposure. Halonen et al. (2015) found that road traffic noise is associated with increased cardiovascular morbidity and mortality and all-cause mortality in London, even after correction for the effects of traffic pollution.

The higher levels of road traffic in areas where people who are socially excluded tend to live often lead to community severance by limiting social interaction with friends and neighbours leading to lower levels of wellbeing (Boniface et al., 2015).

\section{Interventions}

Having highlighted the way that transport-related social exclusion affects health, the final section of this paper will discuss examples of interventions from Britain which have helped socially excluded people to overcome barriers to travel. Because they tend to use the bus, any initiative that makes bus use easier is likely to help them to reach more opportunities.

\subsection{Cost}

There are several ways in which the cost of travel can be reduced. A key issue is to help people who are unable to seek employment because they cannot afford to travel. Work Wise (2012) often working with Passenger Transport Executives in the conurbations and Job Centre Plus, combines personalised journey planning with free or discounted tickets to enable people to get to interviews or a new job. For example, in the West Midlands, it helped over 14,000 job seekers back to work. More than $80 \%$ of customers would have struggled to access employment opportunities without the travel passes provided (pteg, 2010). In London, free travelcards are offered by Transport for London (2015). These allow 
travel on public transport at half the adult rate for up to three months by people on Jobseekers Allowance and those on Incapacity Benefit, Employment and Support Allowance, or Income Support if they are actively engaged with an advisor on returning to employment.

Greener Journeys (2013) which is a consortium of large bus companies, has proposed a scheme called 'Bus bonus' which would offer tax relief on season tickets for bus users and the introduction of more discounted travel for young people, starting with a scheme for apprentices.

Local authorities are required to provide free home-to-school transport for young people aged 5-16 who are attending their nearest school which is more than walking distance away (pteg, 2014). Some local authorities offer more than the statutory minimum: Surrey County Council (2013) offers financial help for travel to school and college above the age of 16 under some circumstances.

In some places, there are cards for young people such as the Mi Card in Barnsley offering free off-peak bus travel and free swimming which also acts as a library card to enable them to participate in more activities (pteg, 2010).

One initiative that was set up especially to address social exclusion was the concessionary travel pass which offers free off-peak bus travel for people over the female state pension age and disabled people (Mackett, 2014b). There is some direct evidence of health benefits. For example, Whitley and Prince (2005) in their study in the Gospel Oak neighbourhood in North London found that, for residents with a common mental disorder, the pass allowed them to access services, facilities and social support outside the neighbourhood which appeared to ameliorate some of the symptoms of their condition and prevent deterioration. This is in addition to all the benefits from improved access, reduced social isolation and improvements to wellbeing (Mackett, 2014a).

\subsection{Availability of transport}

A lack of transport may prevent people from finding employment. To combat this, the Wheels to Work scheme provides vehicles, usually mopeds or motorcycles, mainly to young people in rural areas who have an offer of a job or training (W2W, 2014).

New bus services can provide access to employment for those without cars. For example, new bus routes in St Helens in Merseyside funded by the St Helens Chamber of Commerce were introduced to serve the Haydock Industrial Estate and changes were made to bus routes, plus timetable changes, in South Yorkshire to serve the ASOS Unipart distribution park (pteg, 2014). In the latter case over $75 \%$ of the candidates for jobs did not drive nor have access to vehicles.

New bus services can also help meet social needs. For example, the GEM Centre in Wolverhampton supports children with disabilities and special needs but it was built on an isolated site which was inaccessible from some poorer areas. A dedicated bus service was introduced which led to a $60 \%$ reduction in the number of missed appointments (pteg, 2014). Lucas et al. (2009) examined the value of new three bus schemes in deprived neighbourhoods and found that they improved the quality of life of the local population. In one case, in Braunstone in Leicestershire, accessing healthcare at the local hospital was the most popular use of the bus service. 
Special bus services can save public money: for example, a Ring and Ride bus service in the West Midlands serving 31,000 blind and disabled people saved between $f 13.4 \mathrm{~m}$ and $f 58.5 \mathrm{~m}$ by reducing the need for care, home help and meals on wheels (pteg, 2014).

Where bus services are not viable, volunteers can provide transport services, such as the Volunteer Driving Service operated by the Retired Senior Volunteer Programme (RSVP) North East, which uses older drivers to offer transport to people who need to attend health appointments and collect repeat prescriptions (Centre for Social Justice, 2010).

\subsection{Psychological barriers}

Psychological barriers can be addressed by giving greater confidence to the traveller. Travel training is provided by some local authorities and passenger travel executives (PTEs) to help young people with special education needs to build up their confidence and skills in using buses (pteg, 2014). Many PTEs issue disability guides to provide information about ways of using public transport services. Journey assistance cards are being issued by many PTEs and bus operators (Confederation of Passenger Transport, 2014). These are cards with messages that state the disability or particular needs of the traveller, such as sitting down before the bus moves off or difficulty handling small coins. They can be shown discretely to a bus driver who can provide suitable assistance. Specific examples of assistance are the pads of 50 tear-off slips to help people with speech or hearing impediments and the bus hailer card issued by Centro in the West Midlands which shows the bus number that a blind person requires and can be used to stop a particular bus (pteg, 2010). These schemes can all be complemented by better training of staff, particularly bus drivers (Department for Transport, 2011). The training may be aimed at specific groups such as the dementiafriendly bus services in Northumberland (Alzheimer's Society, 2015).

\subsection{Physical barriers}

Physical barriers can usually be addressed by means of engineering solutions such as ramps, lifts and escalators to assist in changes of level, mobility scooters and wheelchairs to make door-to-door trips for those who have difficulty walking, and adjustments to traffic signal timings for those who are unable to cross the road within the existing timings (Department for Transport, 2005; Mackett, 2014c).

\subsection{Facilities}

It is not difficult to provide facilities such as benches and bus shelters, which can make travel easier for some people. However, such facilities cost money and so expenditure on them should be based upon a rational analysis of the best way to improve accessibility (Mackett et al., 2008).

\subsection{Information}

Information should be provided in ways that recognise the characteristics of the whole population: a variety of formats, both electronic and on paper, should be used. Written information should use a large font and clear language. On-line information which shows routes should include a variety of accessible routes, including step-free and allowing for a variety of walking speeds since this may affect the overall optimal route.

\subsection{Reducing the externalities of transport}

As discussed above, the externalities of transport of casualties, noise and atmospheric pollution are a function of traffic levels. Hence, ways of reducing traffic, particularly car use 
since cars dominate traffic flows, should reduce the externalities. A variety of approaches can be used including charging for the use of the road, fuel pricing, control of car parking, and providing alternative methods of accessing cars rather than owning them such as car clubs and car sharing (Mackett, 2013).

More specific measures can be used to address particular externalities. For example, road safety interventions have reduced casualties (Bunn et al., 2003; Grundy et al., 2009; Webster and Mackie, 1996). By reducing traffic speed and introducing traffic calming measures, many streets have become safer for pedestrians and cyclists, encouraging walking and cycling (Killoran et al., 2006; Public Health England, 2013).

\section{Conclusions}

Transport plays a key role in the prevalence of social exclusion because limited access to opportunities can be a key factor. Improving access can improve wellbeing for many groups in society. By improving transport, access to opportunities for healthier lifestyles can be made available to those who are excluded from society. The adverse effects of transport, which tend to affect those who are excluded the most, can be mitigated by reducing levels of traffic.

Whilst the types of initiative to reduce transport-related social inclusion discussed in this paper will require expenditure by the public and private sectors, they will enable many socially excluded people to make greater contributions to society. The value of the benefits of these may exceed the cost (Mackett, 2015).

There is no panacea to tackle social exclusion. Improving transport will not, on its own, reduce social exclusion. However, many other possible solutions such as providing jobs and training require the provision of suitable transport in order to be successful. Transport needs to be integrated into packages of measures to reduce social exclusion. This will help to enhance the health of people who are socially excluded.

\section{References}

Abdalla, I.M., Raeside, R., Barker, D., 1998. Linking Road Traffic Accident Statistics to Census Data in Lothian. Edinburgh: The Scottish Government. Available from www.scotland.gov.uk/Publications/1998/12/d501f66f-5834-44a2-9ab9-41aa61b7b163.

ACEVO Commission on Youth Employment, 2012. Youth unemployment: the crisis we cannot afford. Available from http://www.nuffieldfoundation.org/sites/default/files/files/ACEVO\%20Youth\%20Unemplym ent lo res.pdf.

Alzheimer's Society, 2015. Drivers for Change: Dementia-friendly bus transport in Northumberland. Available from http://www.alzheimers.org.uk/site/scripts/documents info.php?documentID=2282\&pageN umber=5. 
Andersen, L.B., Schnohr, P., Schroll, M., Hein, H.O., 2000. All-cause mortality associated with physical activity during leisure time, work, sports, and cycling to work, Archives of Internal Medicine. 160, 1621-1628.

Balcombe, R. J. Vance, C. E. (1998) Information for bus passengers: a study of needs and priorities, TRL330, available from http://www.trl.co.uk/reportspublications/report/?reportid=2493.

Boniface S., Scantlebury R., Watkins S.J., Mindell J.S. (2015) Health implications of transport: Evidence of effects of transport on social interactions, Journal of Transport and Health. 2, 441-446. doi:10.1016/j.jth.2015.05.005.

Bostock L., 2001. Pathways of disadvantage? Walking as a mode of transport among lowincome mothers. Health and Social Care in the Community. 9, 11-18.

Bowyer, S., Caraher, M., Eilbert, K. Carr-Hill, R., 2009. Shopping for food: lessons from a London Borough, British Food Journal. 111, 452-474.

Brown, O., 2008. Barriers to Participation: A review of why specific communities in Northern Ireland do not use the countryside for recreation. Countryside Access and Activities Network.

Bunn, F., Collier, T., Frost, C., Ker, K., Steinbach, R., Roberts, I., Wentz, R., 2003. Area-wide Traffic Calming for Preventing Traffic Related Injuries. Cochrane Database of Systematic Reviews, Issue 1. Art. No.: CD003110. DOI: 10.1002/14651858.CD003110.

Available from http://www2.cochrane.org/reviews/en/ab003110.html .

CABE, 2010. Urban Green Nation: Building the evidence base. Available from http://webarchive.nationalarchives.gov.uk/20110118095356/http:/www.cabe.org.uk/public ations/urban-green-nation.

Campion, J. Greenhalgh, C. Knight, J., 2003. Mind the gap: Leonard Cheshire's social exclusion report 2003. Available from http://www.asksource.info/resources/mind-gapleonard-cheshires-social-exclusion-report-2003.

Centre for Social Justice, 2010. Breakthrough Britain: The Forgotten Age. Understanding poverty and social exclusion in later life. Available from: http://www.centreforsocialjustice.org.uk/UserStorage/pdf/Pdf\%20reports/ForgottenAge.pd f.

Colvile, R.N., Hutchinson, E.J., Mindell, J.S., Warren, R.F., 2001. The transport sector as a source of air pollution. Atmospheric Environment. 35, 1537-1565

Confederation of Passenger Transport, 2014. Journey Assistance Cards: A Passenger's Guide, available from http://www.cpt-uk.org/ uploads/attachment/2930.pdf.

Countryside Agency, 2001, Bentham Moving On - an action plan for Bentham. 
Cummins, S., Findlay, A., Higgins, C., Petticrew, M., Sparks, L., Thomson, H., 2008. Reducing inequalities in health and diet: findings from a study on the impact of a food retail development. Environment and Planning A. 40, 402-422.

Delbosc, A., Currie, G. 2011. Exploring the relative influences of transport disadvantage and social exclusion on well-being. Transport Policy. 18, 555-562.

Department of Health, 2010. Healthy Lives, Healthy People: Our strategy for public Health in England HMSO. Available from http://www.dh.gov.uk/prod consum dh/groups/dh digitalassets/documents/digitalasset/ dh 127424.pdf.

Department for Transport, 2005. Inclusive mobility: A guide to best practice on access to pedestrian and transport infrastructure. Available from https://www.gov.uk/government/publications/inclusive-mobility.

Department for Transport, 2008. Road Casualties Great Britain, 2007. Appendix A Tables Road accidents and deprivation statistics 2007. Available from http://webarchive.nationalarchives.gov.uk/20110503151558/http:/www.dft.gov.uk/adobep df/162469/221412/221549/227755/rcgb2007.pdf.

Department for Transport, 2011. Travel Training: Good Practice Guidance. Available from https://www.gov.uk/government/uploads/system/uploads/attachment data/file/4482/gui dance.pdf.

Department for Transport, 2013. Public attitudes towards buses. Available from https://www.gov.uk/government/statistical-data-sets/att01-attitudes-towards-buses.

Department for Transport, 2014. National Travel Survey. Available from . https://www.gov.uk/government/collections/national-travel-survey-statistics.

DTLR, 2001. Focus on Personal Travel. Available from https://www.esds.ac.uk/government/docs/focusonpersonaltravel2001edition.pdf.

Ellaway A., Macintyre S., Hiscock R., Kearns A., 2003. In the driving seat: Psychosocial benefits from private motor vehicle transport compared to public transport, Transportation Research Part F: Traffic Psychology and Behaviour. 6, 217-231.

Frank, L.D., Andresen, M.A. Schmid, T.L. 2004, Obesity relationships with community design, physical activity, and time spent in cars, American Journal of Preventive Medicine, 27, 87-96.

Furey, S., Strugnell, C., Mcllveen, H., 2001. An investigation of the potential existence of "food deserts" in rural and urban areas of Northern Ireland. Agriculture and Human Values. $18,447-457$. 
Greater Manchester Transport Research Unit, 2008. Food or education - the impact of the rise in the concessionary bus fare in Greater Manchester.

Greener Journeys, 2013. Bus 2020: A Manifesto for the next Parliament. Available from http://www.greenerjourneys.com/wpcontent/uploads/2013/09/GreenerJourneys Bus 2020.pdf.

Grundy, C., Steinbach, R., Edwards, P., Green, J., Armstrong, B., Wilkinson, P., 2009. Effect of $20 \mathrm{mph}$ traffic speed zones on road injuries in London, 1986-2006: controlled interrupted time series analysis. BMJ 2009;339:b4469.

Halonen, J. I., Hansell, A. L., Gulliver, J., Morley D., Blangiardo, M., Fecht D., Toledano M. B., Beevers, S. D., Anderson H. R., Kelly F. J. and Tonne C. (2015) Road traffic noise is associated with increased cardiovascular morbidity and mortality and all-cause mortality in London, European Heart Journal, doi:10.1093/eurheartj/ehv216.

Horten, T., Reed, H., 2010. Where the money goes: How we benefit from public services, Trades Union Congress. Available from http://www.tuc.org.uk/sites/default/files/extras/wherethemoneygoes.pdf.

House, J., Landis, K., Umberson, D., 1988. Social relationships and health. Science. 241 (4865), 540-545.

Johnson D., Mackie, P., 2013. Buses and the economy II: survey of bus users amongst the unemployed, Institute for Transport Studies, University of Leeds. Available from http://www.greenerjourneys.com/wp-content/uploads/2013/09/Unemployment-ReportFinalv2.pdf.

King, K., Stedman, J., 2000. Analysis of air pollution and social deprivation. Available from http://webcache.googleusercontent.com/search?q=cache:dH7KHWtZQQcJ:uk-

air.defra.gov.uk/assets/documents/reports/cat09/aeat-r-env0241.pdf+\&cd=1\&hl=en\&ct=clnk\&gl=uk\&client=firefox-a.

Killoran, A., Doyle, N., Waller, S., Wohlgemuth, C, Crombie, H., 2006. Transport interventions promoting safe cycling and walking. Evidence briefing. NICE. Available from http://cehi.org.uk/Transport Evidence Briefing 05-07\%5B1\%5D.pdf.

Kwaśniewska, M., Kaczmarczyk-Chałas, K., Pikala, M., Broda, G., Kozakiewicz, K., Pająk, A., Tykarski, A., Zdrojewski, T., Drygas, W., 2010. Commuting physical activity and prevalence of metabolic disorders in Poland. Preventive Medicine. 51, 482-487.

Lenoir, R., 1974. Les Exclus: Un français sur dix. Editions du Seuil, Paris.

Lucas, K., Jones, P., 2009. The Car in British Society. RAC Foundation, London.

Lucas, K., Tyler, S. and Christodoulou G. (2009) Assessing the 'value' of new transport initiatives in deprived neighbourhoods in the UK, Transport Policy. 16, 115-122. 
Mackett, R. L., 2013. Reducing car use in urban areas, Chapter 10 in Mackett R. L., May A. D., Kii, M. and Pan, H. (Eds.), Sustainable Transport for Chinese Cities. Emerald, Bingley, pp.

211-230

Mackett, R. L., 2014a. The impacts of concessionary travel passes for older and disabled people - a review of the evidence, Chartered Institute of Logistics and Transport. Available from www.bit.ly/concessionary.

Mackett, R. L., 2014b. Has the policy of concessionary bus travel for older people in Britain been successful? Case Studies in Transport Policy. 2, 81-88.

Mackett, R. L., 2014c. Overcoming the barriers to access for older people, Report produced for the Age Action Alliance. Available from http://ageactionalliance.org/wordpress/wpcontent/uploads/2014/11/Overcoming-the-barriers-to-access-Nov-14.pdf.

Mackett, R. L., 2014d. The health implications of inequalities in travel, Journal of Transport and Health. 1, 202-209.

Mackett R. L., 2015. Improving accessibility for older people - investing in a valuable asset, Journal of Transport and Health. 2, 5-13.

Mackett R. L., Achuthan K., Titheridge H., 2008. AMELIA: A tool to make transport policies more socially inclusive. Transport Policy, 15, 372-378.

Mackett, R. L., Titheridge, H., Achuthan, K., 2011. Improving Access in St Albans - Report on a Consultation Exercise, Report produced in the Centre for Transport Studies at University College London as part of the research programme of the AUNT-SUE Consortium. Available from http://www.aunt-sue.info/toolkit/amelia/consultation.html.

Maddison, D., Pearce, D., Johansson, O., Calthrop, E., Litman, T., Verhoef, E., 2014. Blueprint 5: True Costs of Road Transport. Earthscan, England.

Marsden, G., Jopson, A., Cattan, M., Woodward, J., 2007. Transport and Older People: Integrating Transport Planning Tools with User Needs. SPARC Final Report. Available from http://www.its.leeds.ac.uk/projects/sparc/Final\%20SPARC\%20Report\%20Full.pdf.

Mindell J. S., Watkins S. J., Cohen J. M. (eds), 2011. Health on the Move 2. Policies for health-promoting transport. Stockport: Transport \& Health Study Group.

Murray, L., 2006. Sport, Exercise and Physical Activity: Public Participation, Barriers and Attitudes. Scottish Executive, Edinburgh.

Musselwhite, C., Haddad, H., 2010. An exploration into the travel needs of older people. Available from http://staff.bath.ac.uk/pssiw/traffic/Musselwhite.pdf. 
pteg, 2010. Transport and Social Inclusion: Have we made the connections in our cities? Passenger Transport Executive Group. Available from http://www.pteg.net/resources/types/reports/transport-and-social-inclusion-have-wemade-connections-our-cities.

pteg, 2014. Making the Connections: The cross-sector benefits of supporting bus services. Passenger Transport Executive Group. Available from http://www.pteg.net/resources/types/reports/making-connections-cross-sector-benefitssupporting-bus-services.

Public Health England, 2013. Healthy people, healthy places briefing. Obesity and the environment: increasing physical activity and active travel. Available from https://www.gov.uk/government/uploads/system/uploads/attachment data/file/256796/B riefing Obesity and active travel final.pdf.

Ravulaparthy, S., Yoon, S., Goulias K., 2013. Linking elderly transport mobility and subjective well-being. Transportation Research Record. 2382, 28-36.

Road Safety Analysis Ltd, 2010. Child Casualties Report 2010: A study into resident risk of children on roads in Great Britain 2004-08. Available from http://www.roadsafetyanalysis.org/wp-content/uploads/sites/3/2010/08/Child-CasualtyReport-2010.pdf.

Rowlingson, K. (2011) Does income inequality cause health and social problems? Joseph Rowntree Foundation, available from http://www.jrf.org.uk/publications/incomeinequality-health-social-problems.

Saelens, B.E., Sallis, J.F. Frank, L.D., 2003. Environmental correlates of walking and cycling: Findings from the transportation, urban design, and planning literatures, Annals of Behavioral Medicine. 25, 80-91.

Salam, M.T., Islam, T., Gilliland, F., 2008. Recent evidence for adverse effects of residential proximity to traffic sources on asthma. Curr Opin Pulm Med. 14(1), 3-8.

Sen, A., 2000. Social Exclusion: concept, application and scrutiny. Office of Environment and Social Development. Asian Development Bank.

Social Exclusion Unit, 2001. Preventing Social Exclusion. Available from http://www.bristol.ac.uk/poverty/downloads/keyofficialdocuments/Preventing\%20Social\% 20Exclusion.pdf.

Social Exclusion Unit, 2003. Making the Connections: Final Report on Transport and Social Exclusion, Office of the Deputy Prime Minister.

Surrey County Council, 2013. Post 16 Transport Policy. Available from http://www.surreycc.gov.uk/roads-and-transport/roads-and-transport-policies-plans-andconsultations/roads-and-transport-policies-and-plans/post-16-transport-policy. 
Transport for London, 2015. Jobcentre Plus Travel Discount. Available from http://www.tfl.gov.uk/fares-and-payments/adult-discounts-and-concessions/jobcentreplus-travel-discount?intcmp=1754.

Vaganay, M., Woodside, A.R., Harvey, H., 2003. Child pedestrian traffic exposure and road behaviour. Proceedings of the European Transport Conference, available from http://abstracts.aetransport.org/paper/index/id/1757/confid/9.

Webster, D., Mackie, A., 1996. Review of traffic calming schemes in $20 \mathrm{mph}$ zones. TR Report 215. Available from http://www.trl.co.uk/reports-publications/trlreports/report/?reportid=5097.

Whitley, R., Prince, M., 2005. Fear of crime, mobility and mental health in inner-city London, UK, Social Science \& Medicine. 61, 1678-1688.

Work Wise, 2012. About Work Wise UK. Available from http://www.workwiseuk.org/about/.

W2W, 2014. The Wheels to Work Association. Available from http://www.wheels2workassociation.org/index.php. 